\title{
Exploring The Quality of Life and The Related Factors among The Elderly
}

\author{
Indra Gunawan1, Mei-Hsiang Lin², Hsiu-Chin Hsu ${ }^{3}$ \\ ${ }^{1}$ Universitas Muhammadiyah Tasikmalaya, Indonesia \\ ${ }^{2}$ National Taipei University of Nursing and Health Sciences, Taiwan \\ ${ }^{3}$ Chang Gung University of Science and Technology, Taiwan
}

\section{Article Info}

Article History:
Accepted January 27th, 2020
Keywords:
Elderly; Depression; Quality
of Life

\begin{abstract}
As the rapidly growing population of elderly people in the world that means they would be facing all challenges to their quality of life. As age increases, quality of life is often reported to decline. They are also at risk of mental illness, neurological disorder and more health problems affecting their quality of life. Depression is a common mental disorder among the elderly. The objective of this study is to understand the relationship between depression and quality of life among the elderly in an Indonesian nursing home. This research use the descriptive correlational and cross-sectional design was applied. There were 114 elderly recruited by convenient sampling. The results of this study showed the mean age of the elderly was 71.2 at the time of data collection ranging from 65 to 76 years old. The variables associated with quality of life were age, gender, education, marital status, ethnicity, chronic disease, and depression status. Moreover, the study found that, as predictors, the variables that influenced the quality of life according to relevance were: age, depression status, and educational level. Age and depression status is recognized as significant predictors of the quality of life among the elderly in an Indonesian nursing home. The result of the study would serve as references to the future and related promotion for the same field of the study.
\end{abstract}

\section{INTRODUCTION}

The elderly population in the world is increasing day by day. According to the United Nations in 2017 the population of elderly people age 60 or more was 962 million; twice in 1980, when there were 382 million elderly people worldwide. Moreover, by 2050, the number of elderly is expected to double, is projected to reach nearly 2.1 billion ${ }^{1}$

Indonesia is one of top five most populous countries in the world and it is elderly population is growing rapidly. Based on the 2010 population census, the number of elderly in Indonesia was 18.1 million people (7.6\% of the total population). In 2014, that number had risen to 18,781 milion people. The population is expected to rise exponentially, reaching 27.08 million in 2020 , and 33.69 million in 2025.2

In the future, a large number of elderly people in Indonesia will have both positive and negative consequences. If the elderly are healthy, active and productive they can live independently and will have a positive

Corresponding author:

Indra Gunawan

indrasarkid@yahoo.com

South East Asia Nursing Research, Vol 2 No 1, March 2020

ISSN:2685-032X

DOI: https://doi.org/10.26714/seanr.2.1.2020.1-10 
impact. On the other hand, large numbers of elderly people become a burden if they have health problems that result in increased health care costs and decreased family incomes. Increased disability combined with, lack of social and environmental support is not a friendly situation for the elderly. ${ }^{2}$ Elderly people often encounter several difficulties in old age. The elderly often face several vulnerabilities, both physical and social. These include suffering from chronic illness, loneliness and, in any case, lack of physical protection. Because of their physical weakness or mental disability, they both experience decreasing levels of autonomy themselves and limit the autonomy of other family members. It is a serious problem because it can be led to decreased quality of life (QOL) for the elderly.

The World Health Organization (WHO) has defined QOL as "an individual's perception of life in the context of culture and value system in which he or she lives and with his or her goals, expectations, standards, and concerns". ${ }^{3}$ WHO has recently warned its member states that as people around the world live longer, soaring levels of chronic diseases and reduced QOL were poised to become a global public health challenge. ${ }^{4}$

As the rapidly growing population of elderly people in developed and developing country that means they would be facing all challenges to their quality of life. The challenge is to delay the incidence of disability and ensure QOL will remain optimal among elderly people. ${ }^{5}$ But as age increases, quality of life is often reported to decline. 6 For elderly people, good QOL usually means good living conditions. They can live independently and have many friends. Subjectively, they feel satisfied with their lives and experience a high level of happiness. ${ }^{7}$ Although most elderly have good mental health, they are also at risk of mental illness, neurological disorder and more health problems than younger people. ${ }^{4}$ Depression and dementia are the two most common mental disorders among the elderly; depression is a common affecting about $\%$ of the world's older population. Depression is a common reaction to health problems, and in elderly people, depression was often an underdiagnosed problem. People can be depressed caused by trauma or illness; suffering from an earlier loss, or they may seek health care for somatic complaints that were bodily manifestations of depression. ${ }^{8}$ Depression among the elderly has a high recurrence rate and is usually chronic. ${ }^{9}$ The prevalence of depression among the elderly in nursing home populations is very high. The prevalence rate of depression in nursing homes is three to four times higher than among elderly people living in the community. ${ }^{10}$

The institutionalized elderly commonly experience psychological distress. For instance, in Taiwan, about $43 \%$ of elderly people living in nursing homes experience depressive symptoms, while in Hongkong nursing homes, that number rises to about $65 \% .{ }^{11}$ Mazurek found that in three nursing homes in major cities in Poland, that average score on the Geriatric Depression Scale was $7.2 \pm 3.77$, indicating moderate depression among resident based on the result of his survey of 300 resident.$^{12}$

In Indonesia, one study found that the percentage of elderly people who were depressed in a nursing home was higher than they living at home/ community. Found $39 \%$ of elderly people were depressed living in the nursing home and $30 \%$ of elderly people were depressed living in the community/home. ${ }^{13}$ As the elderly population continues to grow, In China today's elderly who are highly dependent on help are choosing to move to nurse homes, which is related to a decrease in the number of caregivers in the family. ${ }^{14}$ Therefore, a limited study has been conducted to explore the relationship between depressions to the quality of life. For this reason, it is reasonable to ask: 'What are the differences between the diverse health/sickness cultures?', and 'How does 
influence the elderly quality of life?' The objective of this study is to understand the relationship between depression and quality of life among elderly in Indonesian nursing home.

\section{METHODS}

\section{Design}

This study adopted a descriptive correlational and cross-sectional design to collect data using a structured questionnaire with face-to-face interviews.

\section{Participants}

A convenience sampling technique was used. A total of 114 subjects elderly who were recruited from five nursing homes in Bandung City. The inclusion criteria were as follows: (1) Participants must be fluent in Indonesian (2) Participants must be willing to participate in the study and sign an informed consent form (3) Ages 60 years and above (4) Living in a nursing home Bandung. The exclusion criteria consisted of (1) Elderly nursing home residents who are healthcare providers or practitioners (2) Elderly who do not consent after getting information about this study (3) Elderly with dementia.

\section{Data Collection}

The recruitment period was conducted from July 2018 to September 2018. After getting permission from the Institutional Review Board (IRB), the researcher made an appointment with each respondent who was agreed to participate in the research. The researcher has explained the research procedures, explain its purpose, and obtained written informed consent. After the participants pass through these stages, the researcher conducted face-to-face interviews using the questionnaires.

\section{Analysis}

Each participant was assigned a study ID for data entry and then the data entered into IBM SPSS Statistics 20.0 to calculate a total score for each of the questionnaires based on the participants' responses. Descriptive statistics, including frequencies and percentages, used to describe demographic variables such as gender, educational background, ethnicity, and marital status. Sample T-test and one-way ANOVA, Pearson correlation coefficients and stepwise multiple regressions used for univariate analysis.

\section{Ethical considerations}

The study protocol and consent form were approved by the institutional review board of the department of health and also the National Committee of Field Development and Research of Bandung City (Institutional Review Board approval: 16MMHIS92e).

\section{RESULTS}

\section{Descriptive Statistics of the Study Population, Depression Status, and Quality of Life}

'The mean age of the elderly was 71.2 (SD \pm 2.88) at the time of data collection ranging from 65 to 76 years old. The majority of the respondents were female, with 75 (65.8\%) females and 39 (34.2\%) males. Most of the participants $(\mathrm{n}=103,90.4 \%)$, were single including widower and only $11(9.6 \%)$ were married. Regarding the educational background, the majority of respondents ( $\mathrm{n}$ $=61,(53.5 \%)$, are the primary school. As many as 27 (23.7\%) are a junior high school, a total of 11 (9.6\%) elderly have the education until senior high school, and around 15 (13\%) had not completed primary school.

Among several ethnicities, the Sundanese elderly outnumbered the others. Of the elderly in the study population, $61(53.5 \%)$ were Sundanese, 42 (36\%) were Javanese, 
and 11 (9.6\%) were Bataknese. According to their chronic disease of the respondents, around 37 (32\%) elderlies had others disease including complications disease, 21 (18.8\%) elderlies with Hypertension, 23 (20.2\%) elderlies with Diabetes mellitus, 15 (13.2) elderlies with Stroke and around 18 (15.8\%) elderlies had Osteoarthritis (table 1).

Table 1

Demographic characteristics of the respondents

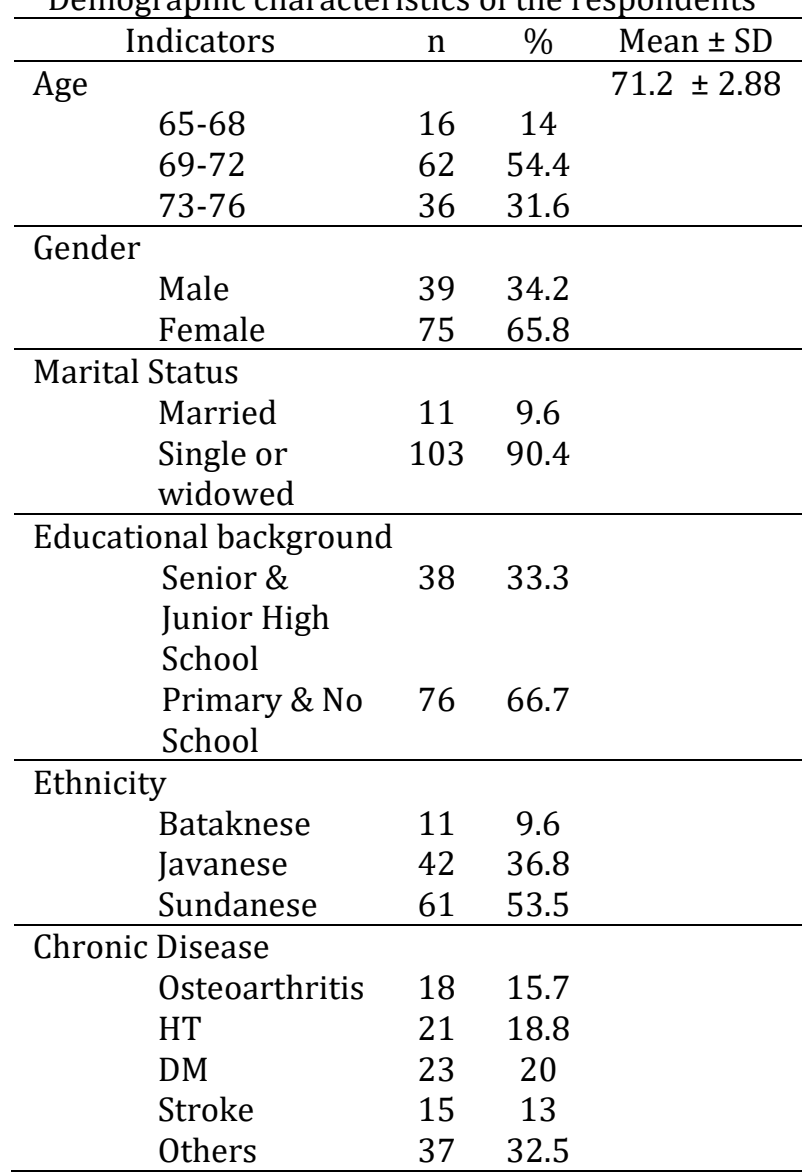

Note, $\mathrm{HT}=$ Hypertension; DM = Diabetus Mellitus; Others $=$ Multiple chronic conditions.

Regarding depression status, the mean depression score among the elderly was 9.17 (SD \pm 2.28). The majority of respondents $(n=61,53.5 \%)$, had moderate depression. As many as 27 (23.7\%) had mild depression, around 11 (9.6\%) elderly had no depression and a total of 15 (13\%) elderly had severe depression (table 2 ).

Meanwhile, regarding the quality of life status, the mean score was 73.46 (SD \pm 13.29). Most of the respondents ( $\mathrm{n}=80$, $70.2 \%$ ) had a moderate quality of life, 23
(20.0\%) respondents had poor quality of life and $11(9.6 \%)$ respondents had a high quality of life (table 2).

Table 2

The distribution of depression status

\begin{tabular}{|c|c|c|c|c|c|}
\hline Indicators & $\mathrm{n}$ & $\%$ & $\begin{array}{l}\text { Mean } \pm \\
\text { SD }\end{array}$ & Min & Max \\
\hline Depression & & & $\begin{array}{l}9.17 \pm \\
2.28\end{array}$ & 4 & 13 \\
\hline $\begin{array}{l}\text { 1. No } \\
\text { Depression }\end{array}$ & 11 & 9.6 & & & \\
\hline $\begin{array}{ll}\text { 2. } & \text { Mild } \\
\text { Depression }\end{array}$ & 27 & 23.7 & & & \\
\hline $\begin{array}{l}\text { 3. Moderate } \\
\text { Depression }\end{array}$ & 61 & 53.5 & & & \\
\hline $\begin{array}{ll}\text { 4. Severe } \\
\text { Depression }\end{array}$ & 15 & 13.2 & & & \\
\hline Quality of Life & & & $\begin{array}{l}73.46 \pm \\
13.29\end{array}$ & 52 & 109 \\
\hline 1. Poor QOL & 23 & 20.2 & & & \\
\hline $\begin{array}{l}\text { 2. Moderate } \\
\text { QOL }\end{array}$ & 80 & 70.2 & & & \\
\hline 3. High QOL & 11 & 9.6 & & & \\
\hline
\end{tabular}

\section{The Difference Between Demographic to Quality of Life}

The result showed that there was a significant difference between the quality of life (QOL) and age variable with $\mathrm{F}=118.01$, $\mathrm{p}<.001$ and post hoc showed a result that the age group of 65-68 years old had better QOL than the age group of $69-72$ years old or over.

Another variables also showed that there were a significant difference between QOL with gender, marital status, and educational background among the elderly with $t=3.24$, $\mathrm{p}=0.002 ; \mathrm{t}=16.72, \mathrm{p}=<0.001 ; \mathrm{t}=10.63, \mathrm{p}$ $=<0.001$ respectively.

Similarly, the statistical result showed that there was a significant difference between QOL and ethnicity among the elderly, with F $=59.28, \mathrm{p}<0.001$ and post hoc showed that Bataknese had better QOL than other ethnicities such as Javanese and Sundanese.

Finally, the result showed that there was a significant difference between QOL and chronic disease among the elderly with $\mathrm{F}=$ $51.34, \mathrm{p}<0.001$, and post hoc test showed 
that the elderly had osteoarthritis had better QOL than HT, DM, Stroke, and others (Table 3).

Table 3

The Significant difference between demographic variables to quality of life

\begin{tabular}{|c|c|c|c|c|c|}
\hline Indicators & $\mathrm{n}$ & Mean \pm SD & $\mathrm{F} / \mathrm{t}$ & $\mathrm{p}$ & Post Hoc \\
\hline \multicolumn{6}{|l|}{ Age } \\
\hline $65-68$ & 16 & $94.88 \pm 10.52$ & 118.01 & $<0.001$ & $(1)>(2)$ \\
\hline $69-72$ & 62 & $75.44 \pm 4.18$ & & & \\
\hline $73-76$ & 36 & $60.56 \pm 10.21$ & & & \\
\hline \multicolumn{6}{|l|}{ Gender } \\
\hline Male & 39 & $79.36 \pm 15.30$ & 3.24 & 0.002 & \\
\hline Female & 75 & $70.40 \pm 11.02$ & & & \\
\hline \multicolumn{6}{|l|}{ Marital Status } \\
\hline Married & 11 & $101.18 \pm 5.11$ & 16.72 & $<0.001$ & \\
\hline Single or widowed & 103 & $70.50 \pm 10.07$ & & & \\
\hline \multicolumn{6}{|l|}{ Educational background } \\
\hline Senior \& Junior School & 38 & $86.84 \pm 9.64$ & 10.63 & $<0.001$ & \\
\hline Primary \& No School & 76 & $66.78 \pm 9.17$ & & & \\
\hline \multicolumn{6}{|l|}{ Ethnicity } \\
\hline Bataknese & 11 & $94.55 \pm 11.24$ & 59.28 & $<0.001$ & $(1)>(2)$ \\
\hline Javanese & 42 & $79.52 \pm 7.93$ & & & \\
\hline Sundanese & 61 & $65.49 \pm 9.83$ & & & \\
\hline \multicolumn{6}{|l|}{ Chronic Disease } \\
\hline Osteoarthritis & 18 & $93.33 \pm 10.85$ & 51.34 & $<0.001$ & $(1)>(2)$ \\
\hline HT & 21 & $78.43 \pm 4.16$ & & & \\
\hline $\mathrm{DM}$ & 23 & $74.13 \pm 3.74$ & & & \\
\hline Stroke & 15 & $71.27 \pm 5.35$ & & & \\
\hline Others & 37 & $61.46 \pm 10.35$ & & & \\
\hline
\end{tabular}

Note HT = Hypertension; DM = Diabetus Mellitus; Others = Multiple chronic conditions.

\section{The Relationship Between Depression and Quality of Life}

This study used Pearson correlation, to determine the relationships between depression status and quality of life among the elderly. The result found that depression status was negatively and significantly related to the quality of life ( $\mathrm{r}$ $=-0.859, \mathrm{p}<0.001$ ) among the elderly (Table 4).

Table 4

The relationship between depression status and quality of life

\begin{tabular}{lcc}
\hline \multicolumn{1}{c}{ Indicator } & $\begin{array}{c}\text { Depression } \\
\text { Status }\end{array}$ & $\begin{array}{c}\text { Quality of } \\
\text { Life }\end{array}$ \\
\hline $\begin{array}{l}\text { Depression Status } \\
\text { Quality of Life }\end{array}$ & 1 & \\
\hline
\end{tabular}

\section{The Factors Predictor of The Quality of Life}

Stepwise multiple regression was used to test the contributions of all independent variables for their influence on basic computer competence. Three predictors variables, including age, depression status, and educational level accounted for $77 \%$ of the variance (Table 5). 
Table 5

The Predict factors of the elderly's quality of life

\begin{tabular}{lcccccrcr}
\hline \multirow{2}{*}{ Indicators } & \multicolumn{2}{c}{$\begin{array}{c}\text { Unstandardized } \\
\text { Coefficients }\end{array}$} & $\begin{array}{c}\text { Standardized } \\
\text { Coefficients } \beta\end{array}$ & $\mathrm{R}^{2}$ & $\begin{array}{c}\text { Adjusted } \\
\mathrm{R}^{2}\end{array}$ & $\mathrm{~F}$ & $\mathrm{p}$ \\
\cline { 2 - 3 } & $\mathrm{B}$ & $\mathrm{SE}$ & & & & & & \\
\hline Age & -0.488 & 0.054 & -0.594 & 0.641 & 0.638 & 199.824 & $<0.0001$ \\
Depression status & -0.142 & 0.018 & -0.601 & 0.730 & 0.725 & 36.461 & $<0.0001$ \\
Educational level & 0.363 & 0.083 & 0.320 & 0.770 & 0.764 & 19.243 & $<0.0001$ \\
\hline
\end{tabular}

\section{DISCUSSION}

\section{Descriptive Statistics of the Study Population, Depression Status, and Quality of Life}

The mean age of the residents was 71.2 years at the time of data collection. Their ages ranged from 65 to 76 years. Almost two-thirds of the respondents were female, with $65.8 \% \quad(n=75)$ female and $34.2 \%$ $(n=39)$ male. This age distribution is similar to that of the population as a whole. Based on data issued by the Indonesian government which shows that life expectancy in Indonesia was approximately 67 years for men and 71 years old for women at the time of data collection. Life expectancy is projected to increase by around 5\% between 2020 and 2030 .

The great majority of nursing home residents, $90.4 \%(n=103)$, were single. The category "single" included widowers, divorced people, and those who never married. At $9.6 \%(n=11)$, less than onetenth of the nursing home residents were married.

As regards education, just over half of the respondents had completed primary school $(n=61,53.5 \%)$, and $23.7 \%(n=27)$ had completed junior high school, with a total of 9.6\% $(n=11)$ completing senior high school, and around $13 \%(n=15)$ had not completed primary school. This population had a notably higher level of education compared to elderly Sundanese as a whole; most older Sundanese are illiterate or have only completed an elementary school education. ${ }^{15}$
Just over half of the participants were of Sundanese ethnicity ( $\mathrm{n}=61,53.5 \%) ; 36 \%$ $(\mathrm{n}=42)$ were Javanese, and 9.6\% $(\mathrm{n}=11)$ were Bataknese. This reflects the fact that Sundanese people are concentrated in the provinces of West Java, Bandung, Jakarta, and the western part of Central Java. ${ }^{16}$

Around $32 \%(n=37)$ of respondents had more than one chronic illness: 21 (18.8\%) had hypertension, 23 (20.2\%) had diabetes mellitus, $15(13.2 \%)$ had had a stroke, and about 18 (15.8\%) had osteoarthritis. As we get older, the risk of chronic disease and comorbidities increases and a person undergoes many changes, including physical, psychological, economic, social and spiritual changes. The age distribution of respondents indicated that most elderly respondents were of advanced age (age 75 or above). At that age, the elderly begin to experience health crises. In line with the research conducted by Kartika in Indonesia, this study found that the participants who experienced depression were in the highest in the age group, 60 to 74 years. ${ }^{17}$

This study found that most depressed residents had moderate depression (53.5\%). Similarly, a study conducted by Mazurek in three nursing homes in major cities in Poland found an average score on the Geriatric Depression Scale was 7.2 \pm 3.77 , indicating moderate depression, based on the results of a survey of 300 nursing home residents. ${ }^{12}$

Among the elderly, depression is often an under-diagnosed problem. Depression may be caused by trauma or illness and suffering from an earlier loss. It is common to seek 
health care for somatic complaints that are bodily manifestations of depression.

\section{The Difference Between Demographic to Quality of Life}

This study found a significant association between demographic factors, such as age, gender, marital status, educational background, ethnicity, and chronic disease, and quality of life.

This study found that age was associated with quality of life among the elderly at five nursing homes in Indonesia. The younger elderly group reported a higher quality of life than the older elderly group. These results are similar to findings from another study conducted by Shah et al in Gujarat, which likewise found that age was related to the quality of life among the elderly, with the older elderly having a lower quality of life than others age groups. ${ }^{18}$

A study conducted in nursing homes in Brazil showed that QOL levels peaked between age 60 and 69, but decreased in every decade of life thereafter so that more than half of people aged seventy-five years and over could be considered to have unsatisfactory QOL.

The results of this study revealed significant differences between genders in terms of quality of life among the elderly at nursing homes in Indonesia. Specifically, elderly males had a better quality of life than females. A study conducted by Khaje et al in Teheran similarly found significant differences between genders, with males having a higher quality of life than females. A survey conducted among 400 elderly people ages 60 years and over also revealed that males got higher scores than the females on quality of life in nursing homes in Marivan City, Iran.

In this study, marital status was significantly associated with quality of life among the elderly in the nursing homes. The results showed that elderly people who were married had a greater quality of life than people who were single or divorced. An association between marital status and quality of life among the elderly has been proven in several studies. For example, the previously found study on elderly people in India found that currently, married people had a better quality of life than people who were divorced, widowed, or separated.

Another factor that is associated with quality of life among the elderly is educational background. The results of this study revealed that the elderly with a higher level of education reported better quality of life than the elderly with lower levels of education. This finding is similar to other studies. For example, Bhatia et al did a study in the district of Ludhiana in India. They found that QOL has a significant correlation with an education background. Specifically, older adults with a high school or higher education had significantly higher QOL scores than elderly people who were illiterate ${ }^{19,20}$. Similarly, quality of life has been reported to be lower among elderly people with less education in Taiwan. ${ }^{21}$

The results of this study found a significant association between ethnicity and quality of life among the elderly. In this study, elderly Bataknese had a higher quality of life than elderly Javanese and Sundanese. Another study conducted by Reeves et al also found a significant QOL difference between ethnic groups in American nursing homes, finding that Mexican Americans had a lower quality of life than non-Hispanics whites in nursing homes. ${ }^{22}$

The results of this study found a significant association between chronic disease and quality of life among the elderly in Indonesian nursing homes. Elderly with multiple chronic conditions had lower quality of life than those who had only one. A study conducted by Canbaz in Turkey which likewise found that elderly people with chronic illnesses scored lower on QOL than the elderly without chronic disease across all four domains. ${ }^{23}$ Similarly, a study 
conducted by Bouchet (2000) found that participants with a history of chronic disease scored higher on all items in each domain of the SF36 Group Questionnaire than those without a history of chronic disease. Furthermore, a study by Leach found that elderly people worried that their physical and mental state would cause emotional distress to others.

\section{The Relationship between Depression and Quality of Life}

The findings of this study revealed a negative correlation between depression levels among the elderly and their quality of life. Results showed that the elderly with the highest level of depression had a lower quality of life, compared to the elderly with a lower level of depression who had a higher quality of life. This association is confirmed by several studies. For example, a study conducted by Chan in China reported that the subjective quality of life is really low among Chinese elderly age 65 years and over with depression, compared with nondepressed elderly. Similarly, Unalan et al. found that depression has a negative relationship to QOL among elderly people, and quality of life is a protective factor against dying. Depression is associated with difficulty adapting. As time goes by, some older persons may partly accept their loss of health and function; adjusting expectations is one way to bridge the gap between what is actual and what is possible. ${ }^{24}$ However, depressive disorder or severity of depressive symptoms in older people are associated with poor psychological resources and coping strategies. ${ }^{25}$

\section{The Factors Predictor of The Quality of Life}

The first factor is age. In this study, revealed that the older elderly groups $(75$ years or over) more often complained about their life are very severe. Living conditions, lack of activities due to physical weakness, illness, an uncomfortable environment and feeling insecure about their physical appearance were currently the trigger factors that increased the burden of life among the elderly. This finding was linearly by the result of the study conducted by Rohmah and Bariyah, that stated that the elderly people reported often experienced unsatisfied feeling the changes in physical, social, cognitive, and vulnerability .26. Another factor that greatly influences the quality of life among the elderly in nursing homes in Bandung, Indonesia was depression. In this study it was revealed that the majority of the elderly in nursing homes in the city of Bandung experienced moderate depression, this might be caused by a lack of activities carried out by the elderly while in institutions and supported by the absence of consultation or psychological examination services for those who are depressed. Depression in the elderly has a serious negative impact on social and physical life where it causes a decrease in the quality of life and causes parents to dependency on others.$^{27}$. Lastly, the educational level was the major predictor that influenced the quality of life among the elderly in Bandung nursing homes. This study found that the majority of the respondent had a low educational level and few of them had higher educational levels such as senior high school. this finding is in line with other studies conducted by Maricha and Wirasto in Indonesia that have found that illiteracy among elderly people age 75 years or older is a problem among elderly living in nursing homes; it has been a concern for a long time in Indonesia.

\section{CONCLUSION}

The study has provided an insight into how the quality of life among the elderly in Indonesian nursing homes. The mean score for quality of life scores among the elderly was 73.46 out of 120 , at the time of data collection. This study included two hundred and fourteen, all elderly at the nursing homes in Bandung City Indonesia. The mean age of the elderly was 71.2 at the time of data collection ranging from 65 to 76 years 
old. Most of the respondents (65.8\%) were female and included several ethnicities, such as Sunda, Batak, and Jawa. There were more students of Sunda ethnicity than any other group. These study findings showed that overall, that variable associated with quality of life were age, gender, educational background, marital status, ethnicity, chronic disease, and depression status. Moreover, age, depression status, and educational level are all predictors of the quality of life elderly in Indonesian nursing homes.

\section{ACKNOWLEDGMENTS}

I want to say thank you to all the family who has participated in success this research, especially to my mother, my father and my lovely wife. And also I want to say thank you to my best advisor for always supporting me and giving me good advice.

\section{CONFLICTS OF INTEREST}

Neither of the authors has any conflicts of interest that would bias the findings presented here.

\section{REFERENCES}

1. de Pauw M. Global Population Aging from a Human Rights Perspective: The Need for a UN Convention on the Rights of Older Persons. Global Europe-Basel Papers on Europe in a Global Perspective. 2017(114).

2. Indonesia KKR. Pelayanan dan Peningkatan Kesehatan Usia Lanjut. Jakarta: Kementerian Kesehatan Republik Indonesia. 2015.

3. WHOQOL W. WHOQOL-Brief introduction, administration, scoring and generic version of the assessment. WHO December. 1996.

4. Shah VR, Christian DS, Prajapati AC, Patel MM, Sonaliya K. Quality of life among elderly population residing in urban field practice area of a tertiary care institute of Ahmedabad city, Gujarat. Journal of family medicine and primary care. 2017;6(1):101.

5. Mohapatra S, Gambir I, Singh I, Mishra N. Nutritional status in elderly people of Varanasi district. Indian J Prev Soc Med. 2010;40(3):15256.

6. Netuveli G, Wiggins RD, Hildon Z, Montgomery SM, Blane D. Quality of life at older ages: evidence from the English longitudinal study of aging (wave 1). Journal of epidemiology and community health. 2006;60(4):357-63.

7. Oguzturk 0. Differences in quality of life in rural and urban populations. 2008. 2008:5.

8. Brunner LS. Brunner \& Suddarth's textbook of medical-surgical nursing: Lippincott Williams \& Wilkins; 2010.

9. Ismail $\mathrm{Z}$, Fischer $\mathrm{C}$, McCall WV. What characterizes late-life depression? Psychiatr Clin North Am. 2013;36(4):483-96.

10. Sun Y, Zhang D, Yang Y, Wu M, Xie H, Zhang J, et al. Social support moderates the effects of selfesteem and depression on quality of life among Chinese rural elderly in nursing homes. Archives of psychiatric nursing. 2017;31(2):197-204.

11. Tsai YF, Chung JW, Wong TK, Huang CM. Comparison of the prevalence and risk factors for depressive symptoms among elderly nursing home residents in Taiwan and Hong Kong. Int J Geriatr Psychiatry. 2005;20(4):31521.

12. Mazurek J, Szcześniak D, Talarska D, Wieczorowska-Tobis K, Kropińska S, Kachaniuk $\mathrm{H}$, et al. Needs assessment of elderly people living in Polish nursing homes. Geriatric Mental Health Care. 2015;2(3-4):9-15.

13. Wulandari AFS, Rahayu RA. Kejadian dan tingkat depresi pada lanjut usia: studi perbandingan di panti wreda dan komunitas: Faculty of Medicine; 2011.

14. Gu D, Dupre ME, Liu G. Characteristics of the institutionalized and community-residing oldest-old in China. Social Science \& Medicine. 2007;64(4):871-83.

15. Sunaryo MK, Wijayanti HR, Kp S, Kep M, Kom S, Kuhu MM, et al. Asuhan Keperawatan Gerontik: Penerbit Andi; 2016.

16. Kurniasih N, Komariah N, Rodiah S. Designing Sundanese Cultural Literacy Programs Based on National Curriculum of 2013 for Students of Elementary Schools in Cileunyi Sub-district, Bandung Regency, Indonesia. INA-Rxiv November. 2017;13.

17. Kartika S. Gambaran Tingkat Depresi Pada Lanjut Usia (Lansia) di Panti Sosial Tresna Wredha Budi Mulia 01 dan 03 Jakarta Timur. Jakarta; 2012.

18. Arslantaş D, Metintaş S, Ünsal A, Kalyoncu C. Eskişehir Mahmudiye ilçesi yaşlılarında yaşam kalitesi. Osmangazi Tıp Dergisi. 2006;28(2):819.

19. Chen H-M, Chen C-M. Factors associated with quality of life among older adults with chronic disease in Taiwan. International Journal of Gerontology. 2017;11(1):12-5.

20. Bhatia S, Swami H, Thakur J, Bhatia V. A study of health problems and loneliness among the elderly in Chandigarh. Indian Journal of Community Medicine. 2007;32(4):255. 
21. Lai K-L, Tzeng R-J, Wang B-L, Lee H-S, Amidon RL, Kao S. Health-related quality of life and health utility for the institutional elderly in Taiwan. Quality of Life Research. 2005;14(4):1169-80.

22. Reeves SL, Brown DL, Baek J, Wing JJ, Morgenstern LB, Lisabeth LD. Ethnic differences in poststroke quality of life in the Brain Attack Surveillance in Corpus Christi (BASIC) project. Stroke. 2015;46(10):2896901.

23. Canbaz S, SÜNTER AT, Dabak S, PEKŞEN Y. The prevalence of chronic diseases and quality of life in elderly people in Samsun. Turkish Journal of Medical Sciences. 2003;33(5):335-40.

24. McDowell I. Measuring health: a guide to rating scales and questionnaires: Oxford University Press, USA; 2006.

25. Sivertsen H, Bjørkløf GH, Engedal K, Selbæk G, Helvik A-S. Depression and quality of life in older persons: a review. Dementia and geriatric cognitive disorders. 2015;40(5-6):311-39.

26. Rohmah AIN, Bariyah K. Kualitas hidup lanjut usia. Jurnal keperawatan. 2015;3(2).

27. Mangoenprasodjo AS. Mengisi hari tua dengan bahagia: Pradipta Publishing; 2005. 